\title{
A Note on the Text
}

This edition of Horrors of Slavery has been retyped from the original 1808 edition, the full title of which is Horrors of Slavery; or, The American Tars in Tripoli. Containing an Account of the Loss and Capture of the United States Frigate Philadelphia; Treatment and Sufferings of the Prisoners; Description of the Place; Manners, Customs, \&c. of the Tripolitans; Public Transactions of the United States with That Regency, Including Gen. Eaton's Expedition; Interspersed with Interesting Remarks, Anecdotes, and Poetry, on Various Subjects. / Written During Upwards of Nineteen Months' Imprisonment and Vassalage among the Turks. The book was published in Troy, New York, by Oliver Lyon, the printer who seems to have withheld the book's plates from Ray (see introduction); it consisted of 298 pages in 16 mo or sextodecimo size, and cost $\$ 1.12$ 1/2. No other edition appeared in Ray's lifetime; in 1911, The Magazine of History reprinted the narrative as an "extra," amending the title to The American Tars in Tripolitan Slavery (The Magazine of History with Notes and Queries. Extra Numbers—No. 13-16 [New York: William Abbatt, 1911]: 255-550). Horrors of Slavery has not otherwise been reprinted; at the time of its publication this edition presents the only scholarly edition of an unabridged Barbary captivity narrative in print.

Ray's frequent use of the long or medial $s(f)$ has been modernized; with the exception of obvious printer's errors, all other irregularities or mistakes in spelling, usage, or expression are Ray's and have been preserved.

All poems included in Horrors of Slavery are by Ray unless otherwise noted. Those poems included in this book were all later reproduced in the first edition of Poems, on Various Subjects, Religious, Moral, Sentimental and Humorous with the exception of "Triumph of Principles: In the election of Governor Tompkins.Quidism deprecated." 
